\title{
Internal organ lesions in patients with acute leukemia according to autopsy data
}

\section{Eldor ISKHAKOV ${ }^{1}$, Khasan TURSUNOV², Saidjalal BAKHRAMOV ${ }^{3}$}

Tashkent State Institute of Postgraduate Medical Education

Tashkent Medical Academy

\section{ARTICLE INFO}

Article history:

Received September 2020

Received in revised form

15 September 2020

Accepted 15 October 2020

Available online

30 October 2020

\section{Keywords:}

Acute leukemia

Chemotherapy

Histological changes in

internal organs.

\begin{abstract}
The analysis of the condition of the internal organs in 17 patients with acute leukemia who died before treatment and at various stages of the antitumor cytostatic treatment was performed. In those cases when patients died before the start of cytostatic treatment, almost all internal organs had a specific lesion of blast cells, which was the cause of death in these patients. In patients who died in a state of myelotoxic aplasia of hematopoiesis, the cause of death was gross dystrophic changes in the internal organs, which led to multiple organ failure due to resistant sepsis.
\end{abstract}

2181-1415/C) 2020 in Science LLC.

This is an open access article under the Attribution 4.0 International (CC BY 4.0) license (https://creativecommons.org/licenses/by/4.0/deed.ru)

\section{SUMMARY}

Thus, the analysis of the state of internal organs in 17 patients with acute leukemia who died before treatment and at various stages of antitumor cytostatic treatment showed that in patients who died before the start of cytostatic treatment, almost all internal organs showed a specific lesion by blast cells, as was the cause of death in these patients. In patients who died in a state of myelotoxic aplasia of hematopoiesis, the cause of death was gross dystrophic changes in internal organs, which led to multiple organ failure caused by resistant sepsis, disseminated intravascular coagulation (DIC), which led to irreversible

\footnotetext{
${ }^{1}$ DSc, associate professor, Head of Department of «Hematology and Transfusiology», Tashkent State Institute of Postgraduate Medical Education, Ministry of Health of the Republic of Uzbekistan, Tashkent, Uzbekistan email: dr.eldor@yahoo.com

${ }^{2}$ DSc, professor, Head of Department of «Pathological Anatomy», Tashkent Medical Academy, Ministry of Health of the Republic of Uzbekistan, Tashkent, Uzbekistan

email: tursunov.hasan@bk.ru

${ }^{3}$ DSc, professor, Department of «Hematology and Transfusiology», Tashkent State Institute of Postgraduate Medical Education, Ministry of Health of the Republic of Uzbekistan, Tashkent, Uzbekistan email: baxramov@mail.ru
} 
changes in internal organs. Our data can provide more detailed information about the histomorphological state of internal organs, a deeper understanding of thanatogenesis in patients with acute leukemia.

\section{Ўткир лейкоз билан касалланган беморларнинг зарарланган ички органларининг аутопсия кўрсатгичлари}

Калит сўзлар:

Ўткир лейкемия

Кимётерапия

Ички органлардаги

гистологик ўзгаришлар.

\section{АННОТАЦИЯ}

Даволашдан олдин ва ўсмага қарши кимётерапия турли босқичларида вафот этган ўткир лейкемия билан касалланган 17 беморда ички органларнинг холатини хистоморфологик тахлил қилинди. Ситостатик даволаниш бошланишидан олдин беморлар вафот этган холларда, деярли барча ички органлар, айниқса, бу хужайралардаги ўлимга сабаб бўлган бласт хужайралар томонидан шикастланган. Кимёвий терапиядан сўнг гемотопезнинг миелотоксик аплазияси холатида вафот этган беморларда ўлим сабаби: ички органларда қўпол дегенератив ўзгаришлар бўлиб, резистент сепсис туфайли кўп орган этишмовчилигининг ривожланиши аниқланди.

\section{Поражение внутренних органов у больных с острыми лейкозами по данным аутопсии}

Ключевые слова:
Острые лейкозы
Химиотерапия
Гистологические
изменения внутренних
органов

Ключевые слова:

Гистологические органов

\begin{abstract}
АННОТАЦИЯ
Проведен гистоморфологический анализ состояния внутренних органов у 17 пациентов с острыми лейкозами, умерших до лечения и на различных этапах противоопухолевой полихимиотерапии. В тех случаях, когда пациенты умерли до начала цитостатического лечения, почти во всех внутренние органах имело место специфическое поражение бластными клетками, что явилось причиной смерти у этих больных. У пациентов, которые умерли в состоянии миелотоксической аплазии кроветворения, после проведенной химиотерапии, причиной смерти были грубые дистрофические изменения во внутренних органах, с развитием полиорганной недостаточности, вследствие резистентного сепсиса..
\end{abstract}

List of abbreviations:

ALL - acute lymphoblastic leukemia

AML - acute myeloid leukemia

AMML - acute myemonoblastic leukemia

APL - acute promyelocytic leukemia

DIC - disseminated intravascular coagulation 


\section{INTRODUCTION}

The transition to programmed chemotherapy for acute leukemia made it possible to achieve long-term remissions bordering on oncological recovery [4,5,6,7]. The use of aggressive chemotherapy protocols leads to the development of severe complications that require intensive concomitant therapy $[8,10]$. The downside of aggressive chemotherapy is hematological and organ toxicity, which is often fatal $[2,9]$. The clinical picture and laboratory parameters cannot provide information on the morphological state of internal organs. Therefore, the most reliable method of histological assessment of the state of internal organs against the background of cytostatic organotoxic therapy is intravital organ biopsy in comparison with laboratory parameters and the results of instrumental diagnostic methods. But, given the practical impossibility of performing an intravital biopsy of internal organs in somatically severe patients, and an extremely small number of scientific works devoted to this topic [1,3], we considered it important to assess the histological state of internal organs using sectional material of deceased patients, to compare them with the neglect of tumor process, to assess the severity of damage to internal organs, depending on the complications that developed after chemotherapy, which led to the death of patients.

\section{PURPOSE OF THE STUDY}

Assessment of histomorphological changes in internal organs in patients with acute leukemia who died at various stages of chemotherapy.

\section{MATERIALS AND METHODS}

Autopsy protocols were selected and analyzed from case histories of 16 patients (8 men and 8 women) aged from 22 to 73 years, median 47.5 years, 8 of them with AML, 2 with APL and 7 with ALL, who died in the period from 2010 to 2018 years in the clinic of The Research Center of Hematology at various stages of treatment. The histomorphological study of autopsy was carried out on the basis of the Republican Center for Pathological Anatomy of the Ministry of Health of the Republic of Uzbekistan

\section{DISCUSSION OF THE RESULTS OBTAINED}

When analyzing the sectional material, we arbitrarily divided the patients into 2 groups:

$1^{\text {st }}$ group - 12 patients with primary acute leukemia.

In thanatogenesis, in primary patients who did not receive cytostatic treatment, in almost all cases, a specific lesion of the internal organs was noted, which served to develop multiple organ failure.

In those cases when induction treatment was carried out, accompanied by a deep aplasia of hematopoiesis, death occurred from septic complications with the development of multiple organ failure and disseminated intravascular coagulation. Deep dystrophy of internal organs, cerebral edema, pulmonary edema were noted microscopically.

As an illustration, we cite the following clinical case, which can be a clear and illustrative example explaining the reason for the severity of the condition of many patients with acute leukemia who seek specific help too late. 
CLINICAL EXAMPLE. Patient T-va M.V. 1999 year of birth I was at the Scientific Center of Hematology from 01/10/2017 to 01/12/2017 with a diagnosis of ALL, hyperleukocytosis. Initially, she was admitted in an extremely serious condition, with symptoms of multiple organ failure. The diagnosis of acute lymphoblastic leukemia was established based on:

1. - Hemogram (CBC) 01/10/2017: - HB - $40 \mathrm{~g} / \mathrm{L}$, Erytrocytes (RBC) $-1.9^{*} 10^{12} / \mathrm{L}$, Platelets $-43.0^{*} 10^{9} / \mathrm{L}$, Leukocytes (WBC) - 121.4*109/L, Blast cells - 94\%, ESR - $50 \mathrm{~mm} / \mathrm{h}$.

2. - Myelogram 01/10/2017.: - Punctate of the bone marrow is moderately cellular. Blastosis - 92.4\%. The red and granulocytic sprout are narrowed. No megakaryocytes were found.

3. - Cytochemical study of bone marrow blasts from 01/10/2017 .: - The reaction of blasts to myeloperoxidase is NEGATIVE, to glycogen - in single blasts POSITIVE in the form of large granules.

Against the background of increasing multiple organ failure, hemorrhagic syndrome, despite the resuscitation measures started, the patient died on January 12, 2017.

Pathological diagnosis (autopsy protocol No. 13 dated 13.01.2017):

Underlying disease: Acute lymphoblastic leukemia. Operation of catheterization of the right subclavian vein from 10.01.2017.

Complications of the underlying disease: bilateral pleurisy. Operation: pleural puncture on the right of 10.01.2017. splenomegaly. DIC syndrome: hemorrhages in the skin, mucous membranes, internal organs, gastrointestinal bleeding. Acute posthemorrhagic anemia. Anemia and dystrophy of parenchymal organs. Pulmonary edema. Cachexia.

Concomitant diseases: Chronic atrophic gastritis. Chronic cholecystitis. Chronic pyelonephritis.

Histological examination revealed a specific leukemic lesion of the internal organs as well as dystrophic changes in the internal organs. (Fig. 1,2,3,4,5,6,7 in the appendix):

Thus, as presented above, in almost all vital organs in this group of patients, dystrophic changes were noted, against the background of specific infiltration of internal organs by blast cells, which caused the death of patients.

$2^{\text {ND }}$ GROUP included 5 patients with acute leukemia, who had received at least 1 course of polychemotherapy during previous hospitalizations. Almost all patients with a resistant course of acute leukemia retained specific infiltration and pronounced degenerative changes in internal organs. In patients who died from resistant sepsis during myelotoxic agranulocytosis, clinical, laboratory and histological signs of multiple organ failure were noted.

We would like to examine in more detail the protocol describing the histomorphological picture of the internal organs of one of these patients.

CLINICAL EXAMPLE. Patient B.I.V., 22 years old, with a diagnosis of AMML, who was in remission of the disease after induction chemotherapy according to the $7+3$ program, the cause of death was the development of resistant sepsis, septic disseminated intravascular coagulation syndrome, septic shock against the background of myelotoxic 
agranulocytosis, after consolidation chemotherapy according to the " $7+3$ " program. Dystrophy of internal organs was noted microscopically.

Protocol for describing morphological changes in the internal organs of patient B.I.V., born in 1990.

Histological examination of autopsy material of tissues and internal organs reveals an uneven distribution of blood in blood vessels of small caliber, with the phenomena of stagnation and accumulation of erythrocytes in the lumen of venules, arterioles and capillaries. In the lumen of large vessels and chambers of the heart, no blood was found; in other vessels, the blood is in a state of postmortal fibrinolysis. Expansion of small-caliber veins, edema of the intima of blood vessels, numerous small hemorrhages, microscopically - agglutination of red blood cells in all small vessels of the microvasculature, numerous blood clots are observed. Attention is drawn to the numerous areas of tissue necrosis in all parenchymal and cavity organs.

KIDNEYS: macroscopically, enlargement, edema and pronounced pallor of the cortical layer are noted. Microscopically, there is anemization of the cortical layer, pronounced necrosis of the epithelial layer, especially in the convoluted tubules, with lysis of the basal membranes of the tubules, edema of the interstitium. Deposition of lysed cells, protein, desquamated epithelium is noted inside the tubules. Almost all microanatomical formations of the renal parenchyma revealed focal necrosis (Fig. 8 in the appendix)

LUNGS: there is an uneven redistribution of blood corpuscles, primarily erythrocytes, with signs of edema of the interstitium and alveoli, numerous small hemorrhages and foci of necrosis, the presence of numerous erythrocyte microthrombi in the lumen of the vessels of the microvasculature (Fig. 9 in the appendix).

LIVER: Macroscopically, the color of the liver is significantly altered, resembles the appearance of "yellow marble chips". Microscopically, dystrophy and necrosis of most of the hepatocytes is noted (Fig. 10 and 11 in the appendix)

MYOCARDIUM: macroscopically discolored, flabby. Microscopically, myocardiocyte dystrophy with symptoms of karyorrhexis, small focal necrotic changes are noted (Fig. 12 and 13 in the appendix)

IN THE STOMACH AND INTESTINES, there are numerous small-point hemorrhages, microthrombi, ulcerative changes in the mucous and submucosal layers, necrosis of the smooth muscle layer of the intestine.

The presented data confirm the fact that the addition of resistant sepsis against the background of myelotoxic aplasia of hematopoiesis leads to the development of multiple organ failure, septic shock, disseminated intravascular coagulation syndrome, which is the main cause of death in patients with acute leukemia.

\section{CONCLUSIONS}

1. Analysis of histological changes in primary patients with acute leukemia revealed specific infiltration of internal organs by blast cells, clinically and laboratory manifestations of multiple organ failure, was the cause of death in patients with acute leukemia.

2. In patients who received induction chemotherapy, the cause of death was the development of multiple organ failure, against the background of resistant sepsis and septic shock during the period of myelotoxic aplasia of hematopoiesis. 
3. The dystrophic changes revealed during histomorphological examination practically in all internal organs reflect thanatogenesis in most patients who died from septic and toxic complications after chemotherapy.

Appendix to the article by E. Iskhakov and Kh.Tursunov

\section{«Internal organ lesions in patients with acute leukemia according to autopsy data»}

\begin{tabular}{|l|l|} 
Figure: 1. Liver: leukemic infiltrates around the \\
triad. Staining with hematoxylin and eosin. \\
Magnification $10 \times 40$
\end{tabular}




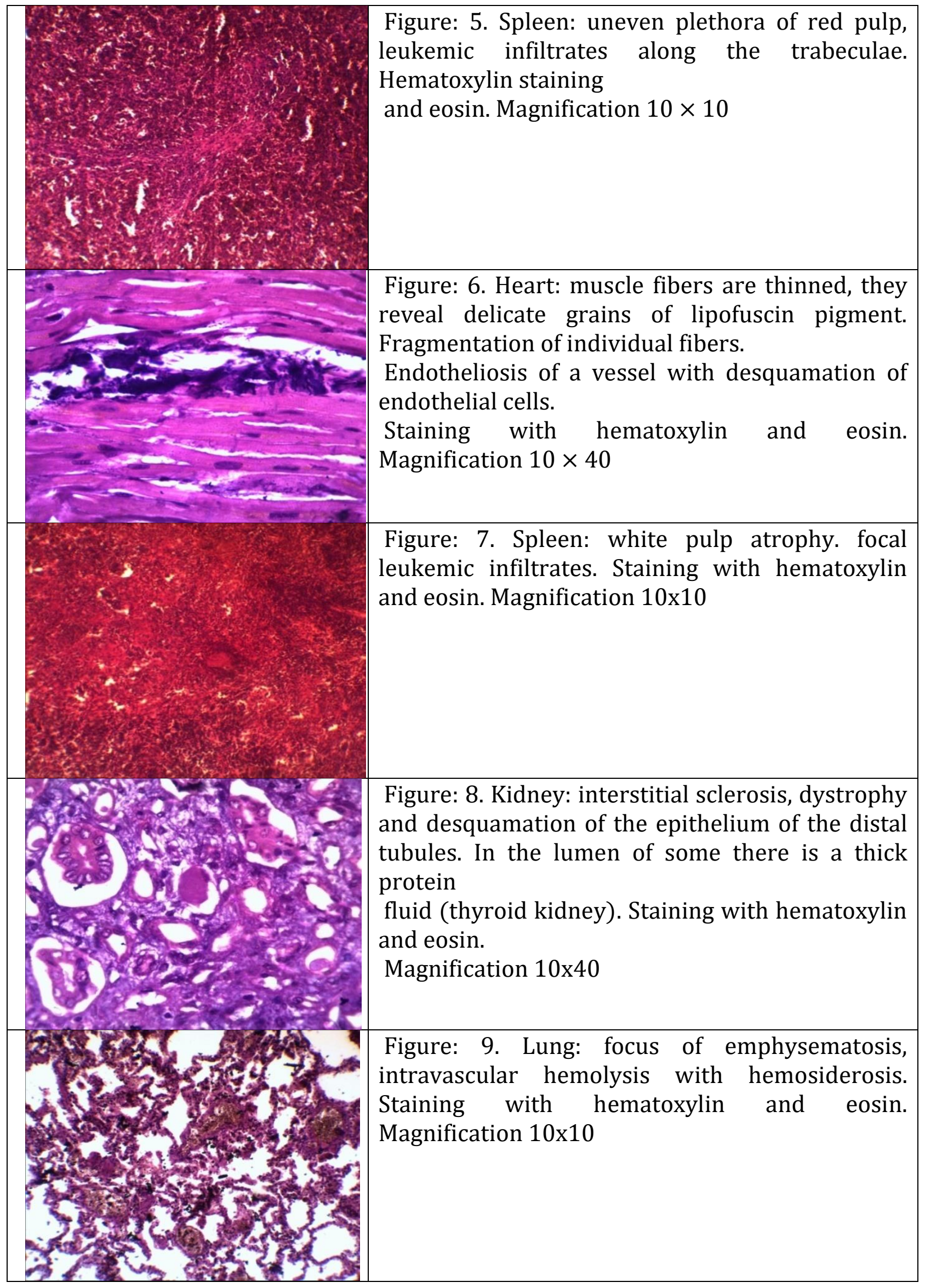




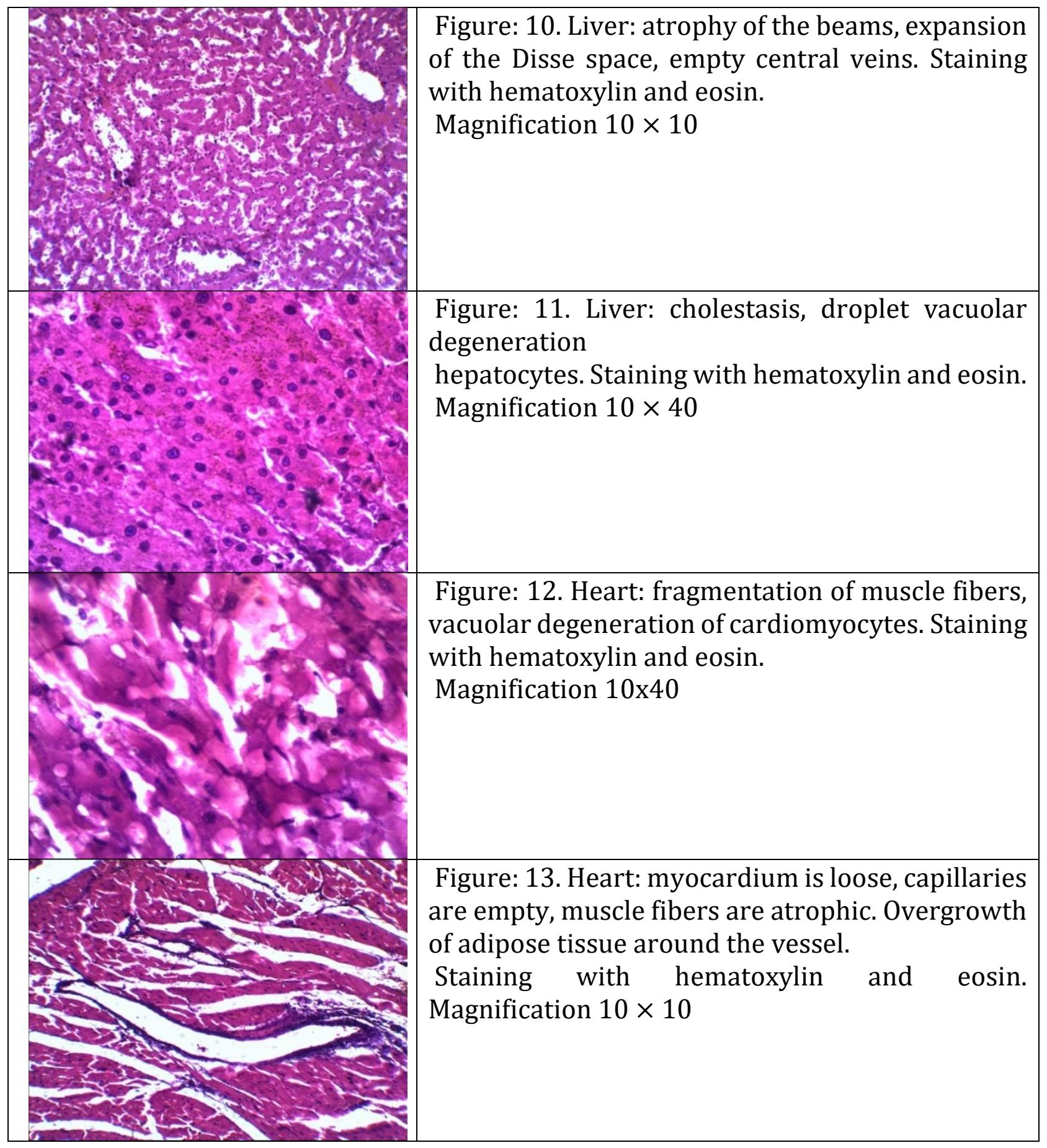

\section{REFERENCES:}

1. Guzovskaya E.V., Serebrennikova S.N. Pathogenetic features of disseminated intravascular coagulation of various etiologies. Pathological physiology and experimental therapy. 2017. Apr. - June; 61 (2): p.76-81.

2. Livshits MS, Boychenko EG, Shabalov NP Influence of postcytostatic leukoneutropenia on the development of infectious complications in children with ALL // Hematology Bulletin. - 2006. - Volume 2, №1. - p. 33-36.

3. Nedzved M.K., Callous E.D. Pathological anatomy. Tutorial. Minsk. 2011.p. 204210. 
4. Parovichnikova EN, Savchenko VG, Davidyan Yu. R. et al. Results of treatment of acute lymphoblastic leukemia in adults according to the ALL-2005 protocol as a basis for new research // Ter. archive. - 2009. - No. 7. - p. 8-15.

5. Parovichnikova EN New treatment programs for acute leukemia // Dissertation for the degree of Doctor of Medical Sciences. - Moscow, 2003.

6. Parovichnikova E. N., Troitskaya V. V., Sokolov A. N. et al. Intermediate results on the treatment of acute Ph-negative lymphoblastic leukemias in adult patients (results of the Russian research group on the treatment of acute lymphoblastic leukemias (RALL) / / Oncohematology. - 2014. - No. 4. - P. 6-18

7. Savchenko V. G. Programmed treatment of diseases of the blood system // Ed .: M .: Praktika, 2012. - p. 289-342.

8. Sarzhevsky V.O., Smirnova E.G., Melnichenko V.Ya. Changes in the gastrointestinal tract during high-dose chemotherapy and autologous bone marrow transplantation in patients with oncohematological diseases // Clinical oncohematology. - 2014. - No. (7-3). - p. 343-352.

9. Gupta A, Singh M, Singh H, Kumar L, Sharma A, Bakhshi S, Raina V, Thulkar S. Infections in acute myeloid leukemia: an analysis of 382 febrile episodes //Med Oncol. 2010, Dec. - Vol. 27, №4. - P. 1037-1045.

10. Kimura S, Wada H, Ishihara Y, Kawamura K, Sakamoto K et al. D-index dose not predict the development of pulmonary infection in acute myeloid leukemia patients undergoing consolidation chemotherapy with high-dose cytarabine// Hematology. 2014, Mar. - Vol. 19, №2. - P. 107-112. 